\title{
Kemampuan Representasi Matematik Siswa Kelas IX MTs pada Materi Bangun Ruang Sisi Lengkung dengan Penerapan Pendekatan Reciprocal Teaching
}

\author{
Santriwati Moka', Heris Hendriana ${ }^{2}$, M. Afrilianto ${ }^{3}$ \\ 1,2,3 IKIP Siliwangi, Jl. Terusan Jenderal Sudirman, Cimahi, Jawa Barat, Indonesia \\ 1 alor25.sm27@gmail.com, ${ }^{2}$ herishen@ikipsiliwangi.ac.id, ${ }^{3}$ muhammadafrilianto@ikipsiliwangi.ac.id
}

Diterima: 31 Januari 2018; Disetujui: 28 Mei 2018

\begin{abstract}
The purpose of this study is to analyze the influence of implementing reciprocal teaching approach as an attempt to improve students' mathematical representation in class IX-B MTs Al-Musyahadah Cimahi on the curved-face three-dimensional-object. The type of research is classroom action research of 2 (two) cycles based on teaching syllabus of the mathematics teacher in class IX-B. Each cycle was conducted based on the learning objectives. The cycle in this study involved the following procedures: Planning; Implementation of action; Observation and evaluation; Reflection. Based on the result of research conducted on the students of class IX-B MTs Al-Musyahadah on the curved-face threedimensional-object material, it revealed the fact that the use of reciprocal teaching approach can improve the ability of mathematical representation, which are; (1) responses and learning outcomes shown in cycle II are primly good, and (2) the students' score of mathematical representation test capability in each cycle has improve significantly, until $87 \%$ on the last cycle . Moreover, the results showed that there are only 4 students from total 29 students who obtain score below 65 . Therefore, Learning by applying reciprocal teaching approach is very effective to use in learning process.
\end{abstract}

Keywords: Mathematical Repretentation, Curved-Face Dimensional-Object, Reciprocal Teaching

\begin{abstract}
Abstrak
Tujuan penelitian ini adalah untuk menganalisis pengaruh penerapan pendekatan reciprocal teaching dalam upaya meningkatkan kemampuan representasi matematik siswa di kelas IX-B MTs AlMusyahadah Cimahi pada materi bangun ruang sisi lengkung. Jenis penelitian ini adalah penelitian tindakan kelas yang terdiri dari 2 (dua) siklus yang didasarkan pada silabus pengajaran guru matematika pada kelas IX-B. Setiap siklus dilakukan berdasarkan tujuan yang ingin dicapai dalam pembelajaran. Siklus dalam penelitian ini meliputi prosedur sebagai berikut: (1) Perencanaan; (2) Pelakasanaan tindakan; (3) Observasi dan evaluasi; (4) Refleksi. Berdasarkan hasil penelitian yang dilakukan pada siswa kelas IX-B MTs Al-Musyahadah pada materi bangun ruang sisi lengkung bahwasanya penggunaan pendekatan reciprocal teaching dapat meningkatkan kemampuan representasi matematik, yaitu: (1) Respon dan hasil belajar yang ditunjukkan siswa pada siklus II tergolong sangat baik dan (2) Nilai tes kemampuan representasi matematik siswa pada setiap siklus mengalami pengingkatan dengan baik, hingga pada siklus terakhir menunjukkan hasil $87 \%$. Berdasarkan hasil tes terlihat bahwa hanya terdapat 4 siswa dari total 29 siswa yang memilki nilai dibawah 65. Pembelajaran dengan menerapkan pendekatan reciprocal teaching sangat efektif untuk digunakan dalam proses pembelajaran..
\end{abstract}

Kata Kunci: Representasi Matematik, Bangun Ruang Sisi Lengkung, Reciprocal Teaching

How to cite: Moka, S., Hendriana, H., \& Afrilianto, M. (2018). Kemampuan Representasi Matematik Siswa Kelas IX MTs pada Materi Bangun Ruang Sisi Lengkung dengan Penerapan Pendekatan Reciprocal Teaching. JPMI - Jurnal Pembelajaran Matematika Inovatif, X (3), 259-268. 


\section{PENDAHULUAN}

Matematika merupakan pengetahuan universal yang mendasari perkembangan teknologi modern di setiap zaman dan memiliki peranan penting dalam kehidupan manusia. Seperti yang diungkapkan oleh Sudrajat (2008) bahwa matematika memberikan ketrampilan yang tinggi pada seseorang dalam hal daya abstaksi, analisis permasalahan dan penalaran logika.selain itu, asalah - masalah yang timbul dalam sektor pertanian, industri, ekonomi dan kesehatan juga dapat dipecahkan dengan pendekatan - pendekatan matematis.

Matematika dikenal sebagai ilmu dasar, pembelajaran matematika melatih kemampuan kritis, logis, analitis dan sistematis. Menurut Peraturan Menteri Pendidikan Nasional (Permendiknas) Nomor 22 Tahun 2006 tentang Standar Isi Mata Pelajaran Matematika untuk semua jenjang pendidikan dasar dan menengah dinyatakan bahwa tujuan mata pelajaran matematika di sekolah adalah agar siswa mampu memahami konsep matematika, menjelaskan keterkaitan antar konsep dan mengaplikasikan konsep atau algoritma, secara luwes, akurat, efesien dan tepat dalam pemecahan masalah (Tristiyati \& Afriansyah, 2016). Selain itu, (Kholiqowati, dkk: 2016) mengatakan bahwa menurut Permendikbud adapun salah satu indikator pencapaian kompetensi tersebut adalah menyajikan konsep dalam berbagai macam bentuk representasi matematis berupa tabel, grafik, diagram, gambar, sketsa, model matematika, atau cara lainnya.

Pencantuman representasi sebagai komponen standar proses, cukup beralasan, karena untuk berpikir matematis dan mengkomunikasikan ide-ide matematika, seseorang perlu merepresentasikannya dalam berbagai cara (Hutagol, 2013). Salah satu materi matematika yang mengambil peran penting dalam kehidupan sehari-hari adalah bangun ruang sisi lengkung. Misalnya berapa banyak cat yang diperlukan untuk mengecat tabung A dengan ukuran yang telah ditentukan. Siswa masih kesulitan dalam memahami konsep dasar mengenai luas permukaan dan volume dari bangun ruang sisi lengkung, sehingga siswa mengalami kesulitan dalam menyelesaikan soal kontekstual yang berhubungan dengan materi ini.

Berdasarkan hasil observasi dan wawancara antara peneliti dan guru mata pelajaran matematika pada kelas IX-B MTs Al-Musyahadah, diperoleh informasi bahwa siswa masih kesulitan dalam memahami masalah yang berkaitan dengan bangun ruang sisi lengkung dan juga belum mampu menvisualisasikan data yang disajikan ke dalam model matematika atau gambar bangun ruang tertentu.

Untuk mengatasi masalah yang telah dikemukakan, kemudian muncul pertanyaan mengenai: metode, pendekatan, atau strategi apa yang cocok untuk diterapkan agar mampu meningkatkan kemampuan representasi matematik siswa yang melibatkan siswa secara optimal. Maka peneliti mencoba menghadirkan pendekatan reciprocal teaching yang dapat mewujudkan tujuan dalam penelitian yaitu meningkatkan kemampuan representasi matematik siswa di kelas IX-B MTs Al-Musyahadah Cimahi pada materi bangun ruang sisi lengkung. Reciprocal teaching adalah (pembelajaran terbalik) merupakan pendekatan terhadap pembelajaran siswa akan strategi-strategi belajar (Thalib dkk, 2016). Pendekatan pembelajaran ini mampu membiasakan siswa untuk menyelesaikan soal dengan tingkat keragaman dan kesulitan yang berbeda.

Pembelajaran dengan pendekatan reciprocal teaching mengajarkan strategi pemahaman mandiri sebagaimana yang diungkapkan oleh Palincsar \& Brown (Zulaihah dkk, 2014)pada pendekatan reciprocal teaching diajarkan beberapa strategi pemahaman mandiri yang spesifik, 
seperti meringkas atau merangkum (summarizing), membuat pertanyaan (question generate), dan menjelaskan atau mempresentasikan (clarifying). Hal tersebut juga dikemukakan oleh Trianto (2007) reciprocal teaching merupakan suatu strategi dimana guru mengajarkan kepada siswa ketrampilan-ketrampilan kognitif dengan menciptakan pengalaman belajar, kemudian membantu siswa mengembangkan keterampilan tersebut atas usaha mereka sendiri. Sejalan dengan hasil analisis data penelitian yang dilakukan oleh Herman, Irwan, \& ZA (2014) yang menyatakan bahwa pemahaman konsep matematika yang menerapkan model reciprocal teaching lebih baik dibandingkan pemahaman konsep matematika yang menerapkan pembelajaran konvensional.

Dasar pengembangan strategi reciprocal teaching adalah siswa diajarkan tentang empat strategi kegiatan yang spesifik dalam memahami suatu bacaan, yaitu: (1)Meringkas bahan bacaan (summarizing); (2)Membuat pertanyaan dan kemudian menjawabnya (questioning); (3)Mengklarifikasi istilah-istilah yang kurang dikenal (clarifying); dan (4)Memprediksi (predicting) materi yang berikutnya, Arends (Sukisnadi dkk, 2014). Secara sederhana kerangka proses pembelajaran digambarkan dalam bentuk prosedur berpikir sebagai berikut:

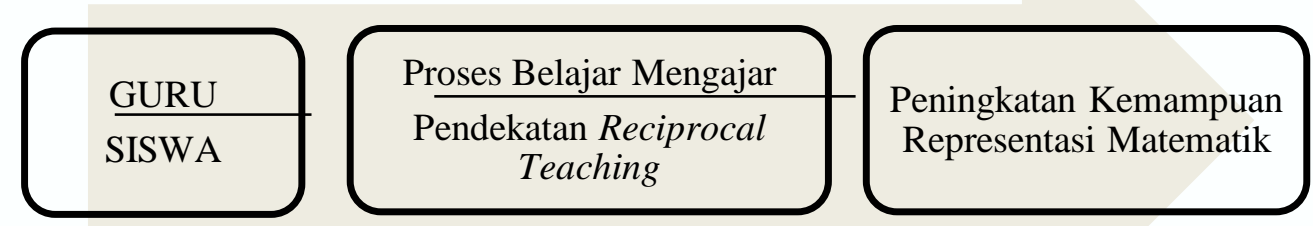

Gambar 1. Prosedur Berpikir Penelitian

\section{METODE}

Penelitian ini penelitian Tindakan Kelas (PTK) atau Classroom Action Research yaitu penelitian yang dimaksudkan untuk memberikan informasi dan gambaran mengenai tindakan dan strategi pembelajaran yang tepat untuk meningkatkan kamampuan guru matematik siswa dan interaktif siswa dalam belajar. Penelitian ini dilaksanakan pada tanggal 08 November sampai dengan tanggal 22 November 2017 pada semester ganjil tahun akademik 2017/2018 di MTs Al-Musyahadah Cimahi. Adapun subjek penelitian pada penelitian ini adalah siswa siswi kelas IX-B dengan jumlah 29 orang yang terdiri dari 15 siswa laki-laki dan 14 siswa perempuan. Adapun rumusan masalah dalam penelitian ini adalah apakah dengan pendekatan reciprocal teaching dapat meningkatkan kemampuan representasi matematik siswa kelas IXB MTs Al-Musyahadah Cimahi umtuk materi bangun ruang sisi lengkung.

Teknik pengumpulan data yang digunakan yaitu: a) Data tentang kondisi pelaksanan pembelajaran bangun ruang sisi lengkung dengan menerapkan pendekatan reciprocal teaching diambil dengan menggunakan lembar observasi terhadap siswa b) Data tentang prestasi belajar diambil dengan menggunakan tes siklus I dan tes siklus II dan c) Data tentang refleksi diri diambil dengan menggunakan jurnal. Penelitian tindakan kelas ini direncanakan terdiri dari 2 (dua) siklus yang didasarkan pada sialbus pengajaran guru maematika pada kelas 
IX-B. Tiap siklus dilakukan berdasarkan tujuan yang ingin dicapai dalam pembelajaran. Sebelum dilaksanakan tindakan kelas, terlebih dahulu dilaksanakan observasi pembelajaran matematika dan wawancara kepada guru metematika yang bersangkutan. Siklus dalam prosedur penelitian ini adalah sebagai berikut:

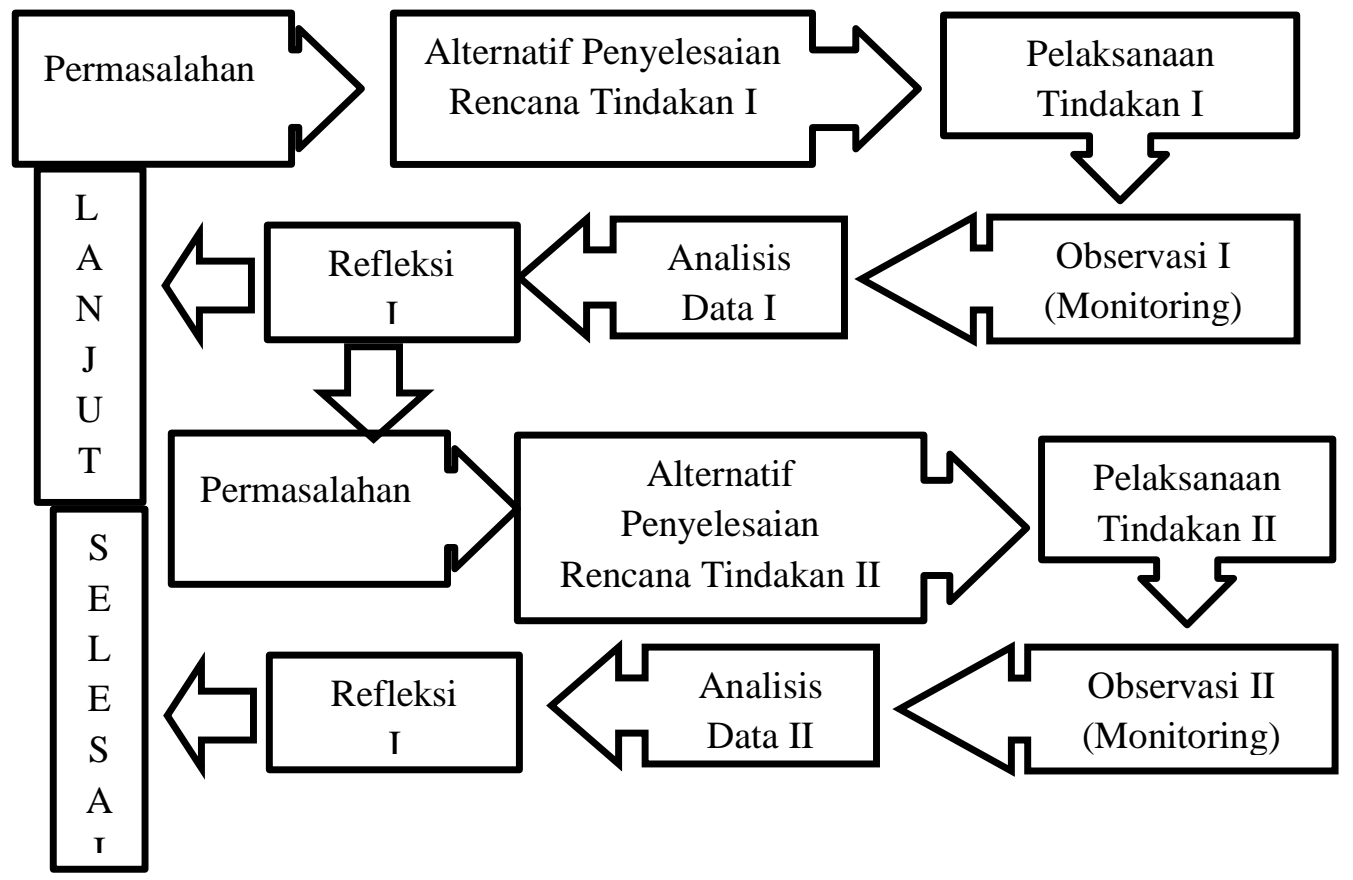

Gambar 2. Prosedur Penelitian

\section{Siklus I}

\section{Perencanaan}

Kegiatan yang dilakukan pada tahap ini meliputi, membuat skenario pembelajaran, mentusun lembar observasi, membuat alat bantu pembelajaran dalam rangka membantu siswa memahami materi yang diajarkan dengan baik, membuat alat evaluasi, untuk menilai penguasaan materi dan melihat peningkatan kemampuan matematik siswa selama pembelajaran, dan membuat jurnal untuk mengetahui refleksi diri. Pada tahap ini adalah dilakukan penyusunan rencana pelaksanaan pembelajaran (RPP) berdasarkan silabus yang dijadikan acuan penelitian. RPP yang dibuat untuk siklus satu terdiri atas 2 pertemuan dengan materi yang diajarkan adalah salah satu bangun ruang sisi lengkung yaitu tabung. Hal penting lainnya adalah kemampuan dan pemahaman guru mengenai materi yang akan diajarkan dan penerapan pendekatan reciprocal teaching.

\section{Pelaksanaan}

Secara sistematis tahap ini menggambarkan tahapan proses pembelajaran: kegiatan pendahuluan, kegiatan inti, dan kegiatan penutup. Tahapan yang direncanakan berdasarkan pendekatan reciprocal teaching yang digunakan seperti: (1) Guru membagikan siswa dalam beberapa kelompok belajar. Guru selaku fasilitator memberikan kebebasan siswa untuk bertanya, berpendapat dan berdikusi, namun tetap di bawah bimbingan guru (2) Siswa diberikan LKS yang berisi tentang langka-langkah menganalisi konsep atau materi pembelajaran (3) Siswa diminta untuk membuat soal, memprediksi jawaban, kemudian mempresentasikan hasilnya. 


\section{Observasi dan Evaluasi}

Pada setiap pertemuan, pengamatan dilakukan sejak awal sampai akhir pembelajaran menggunakan lembar observasi. Setiap aspek yang diamati disusun mengacu pada RPP dan ditujukan terhadap siswa kelas IX-B MTs Al-Musyahadah. Pada akhiri pembelajaran, guru melakukan tes kemampuan untuk siklus I. Beradasarka hasil observasi dan tes kemampuan maka pembelajaran selanjutnya akan direncanakan dan dilaksanakan. Data yang dipeoleh dari hasil observasi mengenai peningkatan kemampuan representasi matematik siswa dan interaksi siswa dalam proses pembelajaran.

Tahap evaluasi dilakukan untuk mengukur pemahaman siswa mengenai materi pembelajaran yang telah dipelajari. Hasil tes menunjukkan bahwa sebagian besar siswa telah memahami konsep materi yang diajarkan. Namun, masih ada siswa yang belum mampu dalam memvisualisasikan sebuah pernyataan ke dalam model matematik maupun gambar visual..

\section{Refleksi}

Pada tahap ini peneliti sekaligus observer menngamati dan menilai keefektifan pelaksanaan pembelajaran dengan menggunakan pendekatan reciprocal teaching dikelas. Selain itu, peneliti juga melihat bagaimana respon murid terhadap penyajian pembelajaran dengan pendekatan ini. Hasil ketuntasan pembelajaran ini akan dijadikan acuan untuk menyusun perencanaan pembelajaran pada siklus selanjutnya.

Berdasarkan hasil obesrvasi terhadap proses pembelajaran dan pemahaman konsep siswa terhadap materi, maka disimpulkan bahwa masih tedapat beberapa kelemahan dan kesulitan. Hasil dan ketuntasan dalam belajar belum memenuhi satandar keberhasilan dalam penelitian ini, sehingga akan dilakukan penelitian tindakan selanjutnya pada siklus II untuk lebih mengkatkan pengusaan dan pemahaman konsep siswa mengenai materi bangun runag sisi lengkung yang diajarkan. Siswa kelas IX-B Al-musyahadah diharapkan mampu menigkatkan kemampuan representasi matematik dengan pendekatan reciprocal teaching yang akan diterapkan.

\section{Siklus II}

Berdasarkan hasil observasi, evaluasi, dan refleksi yang telah dilakukan pada siklus I, maka peneliti sekaligus sebagai guru model merencanakan tindakan siklus II untuk mengatasi dan memperbaiki kelemahan-kelemahan yang terjadi pada pelaksanaan pembelajaran siklus I sehingga memperoleh hasil pembelajaran yang lebih baik. Siklus II merupakan pembelajaran berkelanjutan sebagai penyempurna dari pembelajaran pada siklus I. Secara sisitematis, pada siklus II ini dilakukan: 1) Peninjauan kembali perangkat pembelajaran; 2) Perbaikan komponen-komponen dalam pembelajaran; 3) simulasi dan diskusi kegiatan pembelajarn; 4) Pelaksanaan pembelajaran dilaksanakan sesuai dengan skenario yang telah disusun. Pelaksanaan pembelajaran dilakukan bersamaan dengan kegiatan observasi belajar siswa untuk menganalisis efektivitas dan efisien perangkat pembelajaran yang dikembangkan; 5) Melakukan tes pada akhir pembelajaran untuk menilai hasil belajar terkait peningkatan kemampuan representasi matematis siswa; 6) Mengevaluasi kegiatan pembelajaran yang selanjutnya dilakukan refleksi untuk menganalisis sejauh mana pengaruh pendekatan reciprocal teaching yang digunakan terhadap peningkatan kemampuan representasi matematis siswa.

Pada siklus II siswa dikelompokan secara heterogen dengan jumlah anggota setiap kelompok yang masih sama. Pembentukan kelompok yang heterogen sangat bermanfaat bafi siswa 
untuk bekerjasama dan bertanggung jawab. Materi pembelajaran yang disajikan lebih bersifat kontekstual yang diharapkan siswa mampu melibatkan kemampuan dan mengeksplorkan diri dalam menyelesaikan setiap situasi masalah yang diberikan.

Tabel 1. Faktor-faktor yang Diteliti dan Indikator

\begin{tabular}{|c|c|c|c|}
\hline $\begin{array}{c}\text { Faktor-faktor yang } \\
\text { Diteliti }\end{array}$ & Instrumen & $\begin{array}{l}\text { Metode } \\
\text { Analisis }\end{array}$ & Indikator \\
\hline $\begin{array}{l}\text { Kemampuan } \\
\text { Representasi } \\
\text { Matematik Siswa }\end{array}$ & $\begin{array}{l}\text { Tes Tertulis dan } \\
\text { Kinerja }\end{array}$ & Kuantitatif & $\begin{array}{l}\text { Presentasi keberhasilan hasil tes } \\
\text { mengalami peningkatan dalam } \\
\text { setiap siklus dan dikatakan } \\
\text { berhasil jika } 80 \% \text { siswa } \\
\text { memperoleh nilai diatas } 65 \text {. }\end{array}$ \\
\hline Aktivitas Siswa & $\begin{array}{l}\text { Lembar Pengamatan } \\
\text { (Lembar observasi) }\end{array}$ & $\begin{array}{l}\text { Kualitatif } \\
\text { Deskriptif }\end{array}$ & $\begin{array}{l}\text { Siswa aktif jika sering atau } \\
\text { selalu menampilkan } 8 \text { aspek } \\
\text { yang diamati. }\end{array}$ \\
\hline Aktivitas Guru & $\begin{array}{l}\text { Lembar Pengamatan } \\
\text { (Lembar observasi) }\end{array}$ & $\begin{array}{l}\text { Kualitatif } \\
\text { Deskriptif }\end{array}$ & $\begin{array}{l}\text { Guru melakukan tahapan } \\
\text { pembelajaran secara sistematis } \\
\text { sesuai penyusunan skenario } \\
\text { pembelajaran dan silabus. }\end{array}$ \\
\hline Refleksi Diri & Jurnal & $\begin{array}{l}\text { Kualitatif } \\
\text { Deskriptif }\end{array}$ & $\begin{array}{l}\text { Menjadi pertimbangan } \\
\text { pelaksanaan siklus pembelajaran } \\
\text { selanjutnya. }\end{array}$ \\
\hline
\end{tabular}

\section{HASIL DAN PEMBAHASAN}

\section{Hasil}

Berdasarkan hasil wawancara dan tes kemampuan representasi matematis siswa kelas IX-B MTs Al-Musyahadah Cimahi pada materi bangun ruang sisi lengkung memiliki hasil yang berbeda untuk setiap siklus pembelajaran. Hasil tes pada masing-masing siklus untuk setiap pertemuan menggambarkan pencapaian indikator kemampuan representasi matematis yang berbeda-beda.

Tabel 2. Distribusi Hasil Tes Siklus I

\begin{tabular}{ccc}
\hline Skor & Frekuensi & Presentasi \\
\hline $38-46$ & 2 & $7 \%$ \\
$47-64$ & 9 & $31 \%$ \\
$65-73$ & 7 & $24 \%$ \\
$74-82$ & 8 & $28 \%$ \\
$83-91$ & 3 & $10 \%$ \\
$92-100$ & 0 & $0 \%$ \\
\hline Jumlah & 29 & $100 \%$ \\
\hline
\end{tabular}


Hasil perhitungan pada Tabel 2 menunjukkan bahwa keberhasilan penerapan pendekatan reciprocal teaching pada siklus I menghasilkan nilai yang belum memenuhi kriteria keberhasilan dalam penelitian. Presentasi nilai tes hasil kemampuan representasi siswa pada siklus I hanya mencapai 62\%, sedangkan 11 siswa masih memperoleh nilai dibawah 65 .

Tabel 3. Distribusi Hasil Tes Siklus II

\begin{tabular}{ccc}
\hline Skor & Frekuensi & Presentasi \\
\hline $38-46$ & 1 & $3 \%$ \\
$47-64$ & 3 & $10 \%$ \\
$65-73$ & 8 & $28 \%$ \\
$74-82$ & 8 & $28 \%$ \\
$83-91$ & 5 & $17 \%$ \\
$92-100$ & 4 & $14 \%$ \\
\hline Jumlah & 29 & $100 \%$ \\
\hline
\end{tabular}

Berdasarkan perhitungan hasil tes pada siklus II terlihat bahwa penerapan pendekatan reciprocal teaching pada pembelajaran siklus II memperoleh nilai yang memenuhi indikator keberhasilah dalam penelitian ini. Presentasi nilai tes hasil kemampuan representasi siswa pada siklus II telah mencapai $87 \%$, dimana siswa yang mendapat nilai dibawah 64 hanya 4 orang dari total 29 siswa.

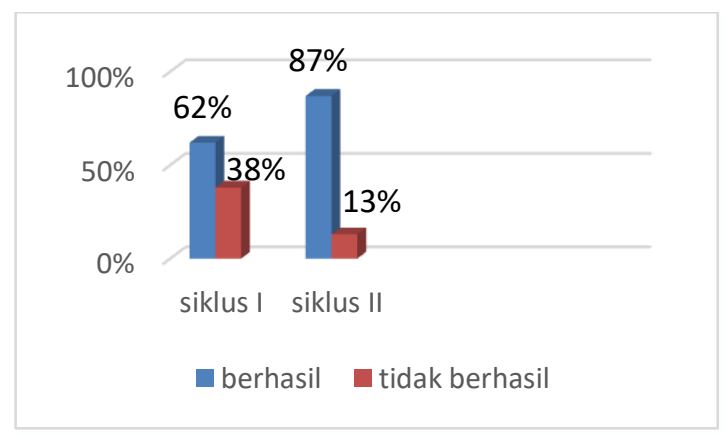

Gambar 3. Perbandingan Hasil Tes Siklus I Dan Siklus II

\section{Aktivitas Siswa dalam Pembelajaran}

Hal yang sama juga terjadi pada aktivitas belajar siswa selama proses pembelajaran. Dalam setiap pertemuan untuk kedua siklus tersebut siswa mengalami peningkatan interaksi dan keaktifan belajar. Pada pertemuan awal mungkin siswa belum bisa beradaptasi dengan pendekatan pembelajaran yang digunakan, dikarenakan pendekatan ini baru pertama kali diterapkan dalam pembelajaran. Namun hingga pada siklus akhir pembelajaran, siswa menunjukkan sikap positif dalam aktivitas dan keberhasilan dalam belajar. Secara keseluruhan ada 8 aspek yang dinilai mengenai aktivitas belas siswa, yaitu: (1) Siswa memperhatikan guru dalam menyampaikan motivasi dan tujuan pembelajaran; (2) Siswa aktif memberikan respon dalam kegiatan aprespsi dan stimulus pada awal pembelajaran; (3) Siswa menyimak dengan baik guru dalam menyampaikan materi pembelajaran; (4) Siswa berdiskusi, memahami, dan menganalisis permasalahan yang disajikan dalam LKS; (5) Siswa aktif mencari dan memilih strategi penyelesaian masalah yang ada pada LKS; (6) Siswa menyimpulkan dan mempresentasikan hasil diskusi kelompoknya; (7) Siswa aktif memberikan tanggapan dan pertanyaan atas penyajian hasil diskusi kelompok lain; dan (8) 
Siswa mampu membuat soal baru dan memprediksi jawaban dari soal tersebut. Dari 8 aspek yang dinilai, rata-rata siswa mengalami kesulitan dalam menyusun soal dan memprediksi jawaban dari soal tersebut. Akan tetapi kekurangan itu dapat diatasi dengan bimbingan dan petunjuk dari guru.

\section{Aktivitas Guru dalam Pengelolaan Pembelajaran}

Guru mengawali kegiatan pembelajaran dengan mengucapkan salam kepada seluruh anggota kelas. Selanjutnya guru meminta ketua kelas untuk memimpin anggotanya berdoa. Selain itu, tidak lupa guru meginformasikan kepada siswa mengenai tujuan pembelajaran dan materi yang akan dipelajari, agar siswa memiliki fokus dan arah yang tepat dalam belajar dan juga guru memberikan kata-kata motivasi untuk meningkatkan minat belajar siswa. Selanjutnya guru menyampaikan pendekatan pembelajran yang akan digunakan selama proses pembelajaran yaitu reciprocal teaching dan manfaat dari penggunakan pendekatan tersebut.

Pada tahap awal pemberian materi pembelajaran, guru membentuk siswa dalam 5 kelompok belajar. Guru memberikan apresepsi untuk menguatkan pemahaman siswa tentang materi yang akan dipelajari yang dilanjutkan dengan guru menjelaskan konsep matematika brdasarkan topik yang dipelajari. Pada tahap berikut guru membagikan LKS kepada setiap kelompok. Siswa setiap kelompok diminta aktif dalam mengerjakan LKS tersebut baik dalam berdiskusi, bertanya, ataupun mengemukakan pendapat.

Guru sebagai mediator dan fasilitator membantu siswa dalam mengalami kesulitan selama pembelajaran. Guru meminta siswa untuk menganalisis dan memahami masalah yang diisajikan kemudian memilih dan menerapkan strategi penyelesaian masalah yang tepat. Guru melakukan pengamatan dan observasi kinerja dan aktivitas siswa secara menyeluruh. Guru juga memberikan penilaian atas kinerja siswa-siswa terbaik agar mereka lebih termotivasi dalam belajar. setelah siswa menyelesaikan masalah pada LKS, guru meminta perwakilan setiap kelompok untuk mempresentasikan jawabannya di depan kelas. Guru beserta murid lainnya memeriksa dan menilai hasil presentasi tersebut, hingga merumuskan jawaban yang tepat. Guru meminta siswa pada setiap kelompok menyusun soal yang lebih sulit dari soal yang telah diberikan, kemudian membuat hipotesis jawaban yang sesuai dengan materi yang telah dipelajari. Pada tahap akhir skenario pembelajaran guru bersama siswa menyimpulkan materi yang telah disampaikan. Kemudian, guru menyampaikan rencana pembelajaran untuk pertemuan berikutnya.

\section{Pembahasan}

Penelitian tindakan kelas (classroom action research) ini terdiri dari dua siklus. Di mana setiap siklus terdiri dari dua pertemuan yang dilaksanakan sesuai dengan prosedur penelitian yang telah disusun. Kuantitas pertemuan dalam setiap siklus tergantung pada kepadatan materi yang dipelajari.

Penelitian ini dilakukan pada kelas IX-B MTs AL-Musyahadah Cimahi dengan menerapkan pendekatan pembelajaran reciprocal teaching yang memiliki langkah-langkah tahapan pembelajaran, seperti: menyimpulkan, menyusun soal, memprediksi, dan mengkonfirmasi. Dengan tahap-tahap pembelajaran ini diharapkan dapat meningkatkan kualitas dan keberhasilan siswa dalam belajar matematika.

Penelitian ini diawali dengan kegiatan observasi awal dan wawancara dengan guru bidang studi matematika MTs Al-Musyahadah Cimahi pada hari senin Senin, tanggal 06 November 2017 pada semester ganjil tahun akademik 2017/2018. Hasil observasi awal dan wawancara, 
masalah yang dirasakan oleh guru tersebut adalah kesulitan siswa dalam memahami konsep materi yang diajarkan serta kebimbangan dan kesulitan guru dalam menerapkan strategi dan pendekatan pembelajaran yang tepat guna menciptakan pembelajaran interaktif. Hal ini berdampak pada penurunan kemandirian belajar siswa dan hasil belajar yang sangat rendah. Tentu hal ini mengharuskan perlu adanya suatu tindakan dalam pembelajaran sehingga dapat meningkatkan penguasaan konsep matematika siswa di kelas tersebut.

Setelah 2 kali pertemuan untuk menyelesaikan kompetensi dasar "Menyelesaikan masalah kontekstual yang berkaitan dengan luas permukaan dan volume bangun ruang sisi lengkung (tabung dan kerucut)" yang merupakan penjabaran dari standar kompetensi "mengidentifikasi unsur-unsur pada bangun ruang sisi lengkung" maka dilakukan evaluasi siklus I pada hari sabtu, 11 November 2017. Tahap ini dilakukan untuk mengukur pemahaman siswa mengenai materi pembelajaran yang telah dipelajari.

Hasil tes menunjukkan bahwa sebagian besar siswa telah memahami konsep materi yang diajarkan. Namun, masih ada siswa yang belum mengusai konsep dasar matematika seperti pengoperasian bentuk aljabar yang melibatkan pecahan.

Berdasarkan penilaian terhadap hasil pengerjaan siswa pada tes siklus I ditemukan $62 \%$ dari total 29 siswa yang memperoleh nilai diatas 65 . Hal ini berarti hanya terdapat 18 siswa yang telah memenuhi ketuntasan dalam belajar.sedangkan terdapat 38\% siswa atau 11 siswa lainnya memperoleh nilai dibawah 65. Secara keseluruhan siswa dinilai cukup dalam memahami materi yang diajarkan, walaupun masih terdapat beberapa pengerjaan soal yang belum sesuai dengan indikator kemampuan matematik yang diharapkan. Hasil penelitian pada siklus I menunjukkan bahwa kemampuan representasi matematik siswa masih kurang.

Setelah 2 kali pertemuan yang dilakukan pada pembelajaran siklus II untuk menyelesaikan kompetensi dasar "Menyelesaikan masalah kontekstual yang berkaitan dengan luas permukaan dan volume bangun ruang sisi lengkung yaitu bola" yang merupakan penjabaran dari sandar kompetensi "mengidentifikasi unsur-unsur pada bangun ruang sisi lengkung" maka dilakukan evaluasi siklus II pada hari sabtu, 15 November 2017. Tahap ini dilakukan untuk mengukur pemahaman siswa mengenai materi pembelajaran yang telah dipelajari dengan mengguakan pendekatan reciprocal teaching. Selain itu, untuk melihat peningkatan hasil belajar dari kegiatan pembelajaran siklus I yang telah dilaksanakan.

Berdasarkan pembelajaran yang telah dilakukan, hasil pelaksanaan tindakan siklus II dapat dikategorikan dalam dua segi yaitu: 1) Dari segi proses: pelaksanaan skenario pembelajaran yang telah dilaksanakan oleh guru telah sesuai dengan RPP yang telah disusun dan telah mencapai indikator yang ditetapkan. 2) Dari segi hasil: berdasarkan pengamatan dan penilaian secara menyuluruh siswa telah mampu memahami materi dengan mencapai ketuntasan dalam belajar yaitu $87 \%$. Hasil tes menunjukan hanya terdapat 4 siswa dari total 29 siswa yang memilki nilai dibawah 65 pada kelas IX-B MTs Al-Musyahadah. Berpedoman pada penyusunan rencana pelaksanaan pembelajaran (RRP) dan indikator kinerja penelitian ini dapat disimpulkan telah tercapai.

\section{KESIMPULAN}

Berdasarkan penjelasan yang telah dijabarkan mengenai penerapan pendekatan reciprocal teaching dalam proses pembelajaran matematika di kelas IX-B MTs Al-Musyahadah Cimahi telah mampu mereasilisasikan tujuan dan indikator Penelitian Tindakan Kelas ini. Terbukti 
dengan penerapan pendekatan reciprocal teaching pada materi bangun ruang sisi lengkung mampu meningkatkan kemampuan representasi matematik siswa dalam setiap siklus pembelajaran.

Selain mampu menjawab rumusuan masalah dalam penelitian, metode Penelitian Tindakan Kelas juga berperan dalam: (1) Meningkatkan pemahaman dan motivasi belajar siswa, dikarenakan dalam proses pembelajaran siswa diminta untuk menyusun soal lain dan memprediksi jawaban soal tersebut; (2) Meningkatkan keaktifan siswa dalam diskusi kelompok, karena merasa dipantau dan dinilai setiap kinerja dan hasil mereka; (3) Mengevaluasi kinerja guru untuk menjadi pengajar yang lebih baik dalam melaksanakan kegiatan pembelajaran; dan (4) Teridentifikasi siswa dan guru memberikan respon yang positif dalam menerapkan pendekatan pembelajaran reciprocal teaching.

\section{DAFTAR PUSTAKA}

Herman, N. A., Irwan, \& ZA, N. (2014). Penerapan Model Reciprocal Teaching Pada Pembelajaran Matematika Siswa Kelas VIII SMPN 26 Padang. Jurnal Pendidikan Matematika, 3, 13-17.

Hutagol, K. (2013). Pembelajaran Kontekstual Untuk Meningkatkan Kemampuan Representasi Matematis Siswa sekolah Menengah Pertama. Infinity Jurnal Ilmiah Program Studi Matematika STKIP Siliwangi Bandung, 2, 85-99.

Kholiqowati, H., Sugiarto, \& Hidayah, I. (2016). Analisis Kemampuan Representasi Matematis Ditinjau Dari Karakteristik Cara Berpikir Peserta Didik Dalam Pembelajaran Dengan Pendekatan Saintifik. Unnes Journal of Mathematics Education, 5, 234-242.

Sudrajat. (2008). Peranan Matematika dalam Perkembangan Ilmj Pengetahuan dan Teknologi. In The Power of Mathematic for all Aplications (pp. 1-12). Bandung: HIMATIKAUNISBA.

Sukisnadi, D., Poedjiastoeti, S., \& Suyanto. (2014). Implementasi strategi Reciprocal Teaching Berorientasi Coorperative Learning Untuk Meningkatkan Hasil Belajar Siswa Pada Materi Pokok Reaksi Redoks Di SMAN 11 Samarinda. Jurnal Penedidikan Sains Pascasarjana Universitas Negeri Surabaya, 1, 420-428.

Thalib, F., Mardiyana, \& Sutrima. (2016). Eksperimentasi Pendekatan Pembelajaran Reciprocal Teaching Dengan Alat Peraga Pada Pokok Bahasan Lingkaran Ditinjau Dari Kreativitas Siswa. Jurnal Elektronik Pembelajaran Matematika, 4, 294-302.

Trianto. (2007). Model-model Pembelajaran Inovatif Berorientasi Kontruktivistik. Jakarta: Prestasi Pustaka.

Tristiyati, T., \& Afriansyah, A. E. (2016). Kemampuan Pemecahan Masalah Matematis Siswa Melalui Model Pembelajaran Koorperatif Tipe Diskurs Multi Representasi dan Reciprocal Teaching. Jurnal Silogisme: Kajian Ilmu Matematika Dan Pemebelajarannya, 1, 4-14.

Zulaihah, N., Witurachmi, S., \& Ivada, E. (2014). Pembelajaran Reciprocal Teaching Model Dengan Strategi Motivasi ARCS Mampu Meningkatkan Hasil Dan Kemandirian Belajar Siswa SMK. Jupe UNS, 3, 34-44. 